\title{
Açaí Seeds as a Prospective Biosorbent for Acid Dyes Removal
}

\author{
R. Rossetto, ${ }^{\mathrm{a}, *}$ G. M. Maciel, ${ }^{\mathrm{b}}$ I. de Andrade Arruda Fernandes, ${ }^{\mathrm{a}}$ \\ T. A. Modkovski, ${ }^{b}$ M. A. Semião, ${ }^{\text {b }}$ T. Brugnari, ${ }^{\text {b }}$ and C. W. I. Haminiuk ${ }^{\mathrm{b}}$ \\ aPrograma de Pós-Graduação em Engenharia de \\ Alimentos (PPGEAL), Universidade Federal do Paraná (UFPR), \\ Curitiba, CEP 81531-980, PR, Brazil \\ doi: https://doi.org/10.15255/CABEQ.2021.1979 \\ ${ }^{b}$ Laboratório de Biotecnologia, Departamento Acadêmico de \\ Química e Biologia (DAQBi), UniversidadeTecnológica Federal \\ do Paraná (UTFPR), Curitiba, CEP 81280-340, PR, Brazil \\ Original scientific paper \\ Received: June 7, 2021 \\ Accepted: September 16, 2021
}

In this study, were used residual Açaí seeds as a biosorbent for two textile dyes (Acid Yellow 219 (AY) and Acid Red 361 (AR)), in single and binary solutions. Further, kinetic and isothermal studies were carried to evaluate if the chemical modifications in the Açaí seeds would promote an increase in biosorption. Kinetic assays for all solutions showed that more than $50 \%$ of the dyes were removed in the first 15 minutes. The acid treatment of the biosorbent increased the removal of acid dyes in solution by $46 \%$ and $32 \%$, respectively. In conclusion, chemically modified Açaí seeds showed high capacity for the removal of textile dyes in single (AY $q_{\mathrm{e}}=1.40 \mathrm{mg} \mathrm{g}^{-1}$; AR $q_{\mathrm{e}}=1.76 \mathrm{mg} \mathrm{g}^{-1}$ ) and multi-component solutions (AY MIX $q_{\mathrm{e}}=2.09 \mathrm{mg} \mathrm{g}^{-1}$; AR MIX $q_{\mathrm{e}}=2.23 \mathrm{mg} \mathrm{g}^{-1}$ ). These results demonstrate that Açaí seeds can be applied in an inexpensive strategy for removing pollutants (single or binary solutions) from wastewater.

Keywords:

biosorption, nonlinear models, kinetic models, selectivity factor, waste management, biomass valorization

\section{Introduction}

The use of dyes in the textile industry has resulted in the significant generation of effluents. Effluents are considered hazardous due to their toxic composition and the coloring of the residual water. As they are very resistant, it is hard to degrade them, and the removal of these compounds requires several treatment steps. ${ }^{1}$ Therefore, adsorption is considered to be an effective technique to solve this particular environmental problem. ${ }^{2}$

Conventional adsorbents such as resins and activated carbon are widely used and have good efficiency. However, the cost is high and the active sites become saturated, generating a new type of potentially toxic waste. ${ }^{3}$ The use of industrial and agricultural waste generated in large amounts (peels and seeds) as a biosorbent, has been studied as a promising alternative and low-cost technique..$^{4-7}$ Usually, theses residues do not have a destination with economic value. ${ }^{8}$ In this context, the large amount of Açaí seeds that result from the pulping process of fruit generates tons of waste annually. ${ }^{9}$ The composition of the Açaí seeds is rich in cellulose, which suggests that this by-product can be

"Corresponding author: tel. number +5541999932430 ;

e-mail: quelrossetto@gmail.com considered for use in the adsorption effluent treatment. ${ }^{10}$

The biosorption kinetics can be influenced by several factors such as temperature, $\mathrm{pH}$, and the initial concentration of the solution, as well as the nature, dosage, and size of the biosorbent beyond the adsorbate characteristics and its interaction with the biological matrix. ${ }^{11-13}$ The presence of more than one dye in textile effluents is common, which makes multi-component biosorption more complex due to the competition for active sites by the different adsorbates. ${ }^{14}$ This results in the search for biosorbents with desirable characteristics, such as a specific surface area, pore volume, and accessible biosorption sites. ${ }^{15}$

Considering that few studies elucidate the mechanisms of interaction of more than one dye in solution with the adsorbent, tests were carried out in single and binary solutions. Thus, the effect of the solution $\mathrm{pH}$, the acid treatment of the biosorbent, and temperature conditions were evaluated to elucidate the adsorption mechanisms through the kinetic and isotherm analyses. Furthermore, this is the first study to propose the use of Açaí seeds as biosorbent for dyes removal, which is a new and inexpensive strategy for removing pollutants from industrial wastewater. 


\section{Materials and methods}

\section{Reagents}

All reagents used had an analytical purity degree $(>99 \%)$. Hydrochloric acid and sodium hydroxide were purchased from Sigma-Aldrich (St. Louis, MO, USA). The Acid Yellow 219 and Acid Red 361 dyes were supplied by a textile industry company (Curitiba, PR, Brazil).

\section{Dye solutions}

In this work, two synthetic dyes were used: Acid Yellow 219 (AY) $\left(\mathrm{C}_{20} \mathrm{H}_{17} \mathrm{~N}_{4} \mathrm{NaO}_{5} \mathrm{~S}-\right.$ molecular mass $448.43 \mathrm{~g} \mathrm{~mol}^{-1}$ ), and Acid Red 361 (AR) $\left(\mathrm{C}_{23} \mathrm{H}_{25} \mathrm{~N}_{4} \mathrm{NaO}_{6} \mathrm{~S}_{2}-\right.$ molecular mass $\left.540.59 \mathrm{~g} \mathrm{~mol}^{-1}\right)$. A stock solution containing $1000 \mathrm{mg} \mathrm{L}^{-1}$ of each dye was prepared, and the necessary dilutions were performed (Fig. 1, step 3). The colorimetric method was used to quantify the concentration (Fig. 1, step $6)$ of the dye solution where the maximum absorbance $(\lambda)$ of the dye was measured using a spectrophotometer (UV-M51 BEL Engineering, Monza, MB, Italy). Seven known concentrations of the solution (10-100 $\mathrm{mg} \mathrm{L}^{-1}$ ) were used for the calibration curve, $\mathrm{AY}$ at $384 \mathrm{~nm}\left(\mathrm{Abs}=0.028 \mathrm{C}-0.99 ; R^{2}=0.998\right)$, and $\mathrm{AR}$ at $511 \mathrm{~nm}\left(\mathrm{Abs}=0.022 \mathrm{C}+0.005 ; R^{2}=0.999\right)$. A calibration curve was also constructed using the two wavelengths for each dye in a binary solution to reduce the interference in the final absorbance. The $384 \mathrm{~nm}$ curve provided the concentration of Acid Yellow in the binary solution (AY MIX) $\left(\right.$ Abs $\left.=0.030 \mathrm{C}-0.023 ; R^{2}=0.999\right)$ and the $511 \mathrm{~nm}$ curve provided the Acid Red concentration in the binary solution (AR MIX) $(\mathrm{Abs}=0.026 \mathrm{C}+0.005$; $\left.R^{2}=0.999\right)$.

\section{Biosorbent preparation}

The purple Açaí seeds were collected in the city of Belém (Pará state- Brazil), crushed for 30 minutes using a mill, and homogenized in sieves (MESH <80). The larger particles went through grinding again until reaching the desired size, Fig. 1 (steps 1 and 2). After processing, the seeds were placed in an Erlenmeyer flask for the acid treatment, according to the methodology proposed by Rubio et al. ${ }^{16}$ The seeds were kept in an $\mathrm{HCl}$ solution $0.1 \mathrm{M}$ for 24 hours. The samples were then washed with deionized water to remove the acid before being centrifuged for 10 minutes at $6000 \mathrm{rpm}$, and lyophilized for 72 hours. The acid treated and untreated seeds were packaged and stored at $-20^{\circ} \mathrm{C}$.

\section{Biosorbent surface characterization}

The biosorbent characterization was performed at Centro de Microscopia Eletrônica (CME - UFPR). The samples in powder form (Fig. 1, step 7) without treatment (WT), with acid treatment (AT), and after biosorption were dispersed onto copper tape for the analysis of the elemental composition of the surface using an energy dispersive $\mathrm{x}$-ray detector (EDS) (Fig. 2). For the analysis of the extracellular structure, the samples were coated with $90 \mathrm{~nm}$ gold for scanning electron microscopy (SEM) according to the equipment specifications (Tescan, Vega3 LMU, Brno, CZ), operating at $10 \mathrm{kV}$ from 100 to $1000 \mathrm{x}$.

\section{Zero charge point determination}

The zero charge point $\left(\mathrm{pH}_{\mathrm{PZC}}\right)$ of the untreated and modified biosorbent was determined following the "eleven point experiment" methodology. ${ }^{17}$ The
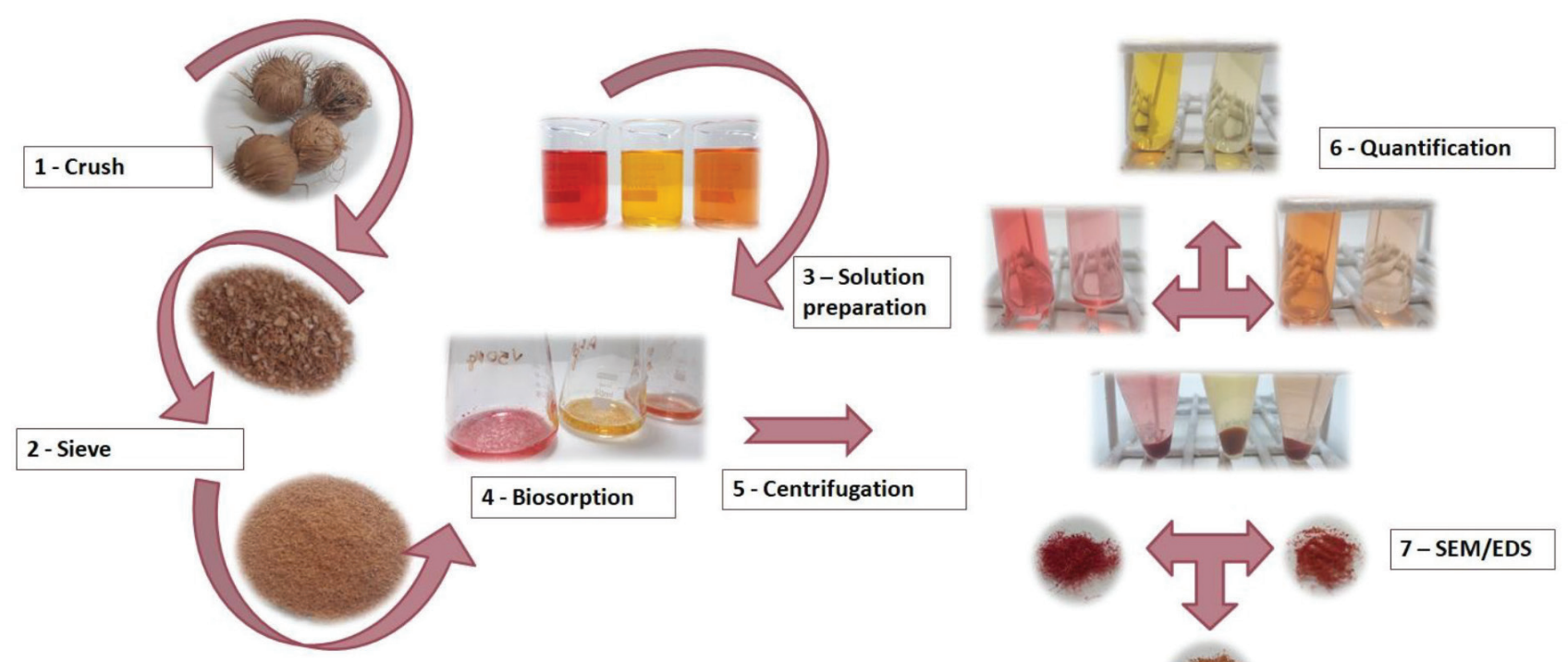

Fig. 1 - Experimental procedure: detailed steps of dye biosorption in Açai seeds 

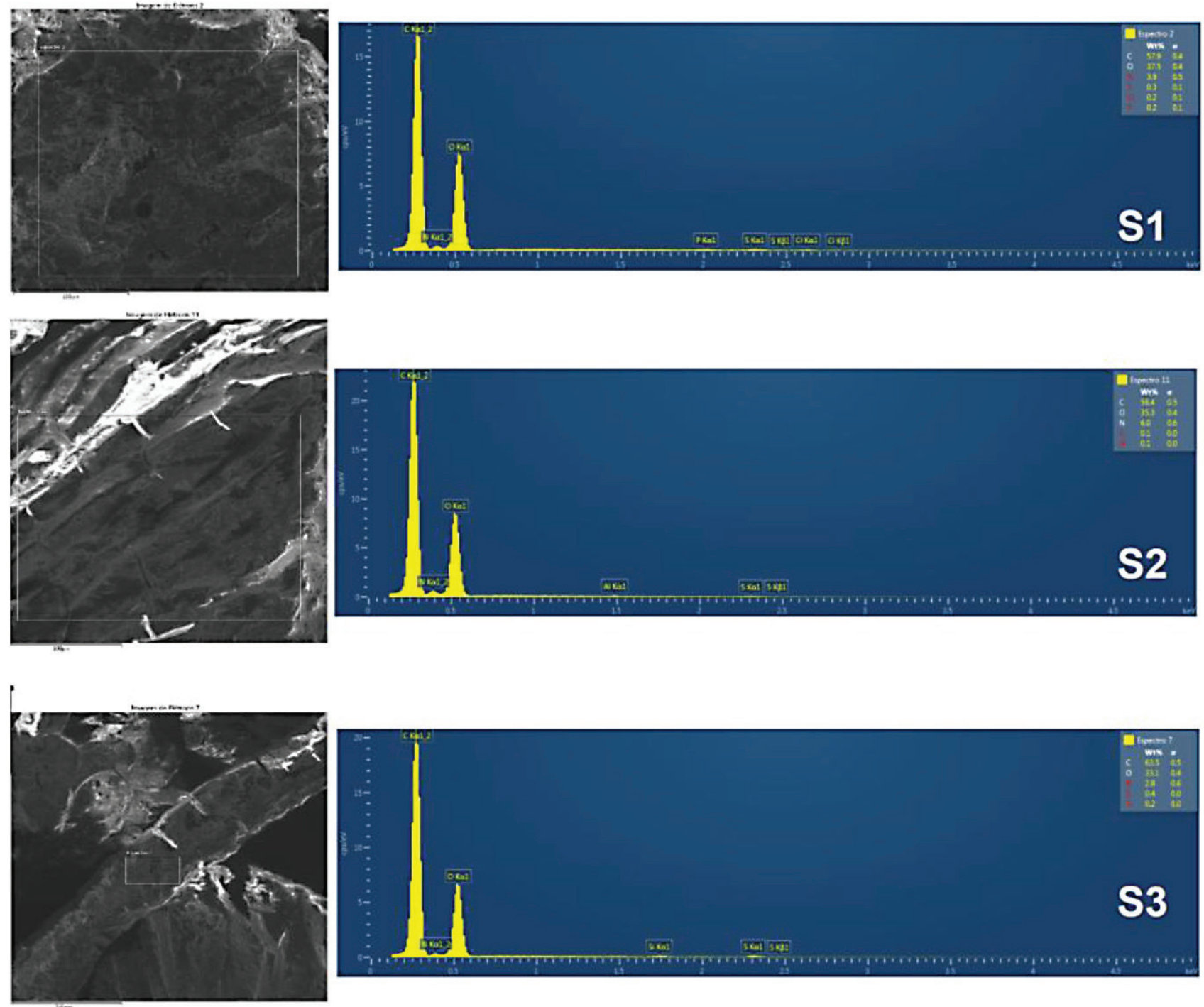

Fig. 2 - EDS (energy dispersive X-ray analysis) after adsorption of the dye on Açai seeds (where S1, S2 and S3 are the three different structures of the seeds)

procedure consisted of preparing aqueous solutions of $50 \mathrm{~mL}$ for 11 initial $\mathrm{pH}$ conditions $(1,2,3,4,5$, $6,7,8,9,10,11)$ adjusted with solutions of $0.1 \mathrm{M}$ hydrochloric acid and $0.1 \mathrm{M}$ sodium hydroxide, to which $0.05 \mathrm{~g}$ of the biosorbent were added. After 24 $\mathrm{h}$ of contact, the equilibrium $\mathrm{pH}$ values of the samples were measured using a pHmeter (Gehaka PG200- São Paulo, SP, Brazil). With the values obtained, a graph of the initial $\mathrm{pH}\left(\mathrm{pH}_{\mathrm{i}}\right)$ versus the final $\mathrm{pH}\left(\mathrm{pH}_{\mathrm{f}}\right)$ was built, where the $\mathrm{pH}_{\mathrm{pZC}}$ was determined at the range in which the $\mathrm{pH}$ remained constant.

\section{Initial pH effect}

The $\mathrm{pH}$ values of the dye solution $\left(20 \mathrm{mg} \mathrm{L}^{-1}\right)$ were adjusted using a $0.1 \mathrm{M}$ hydrochloric acid solution and $0.1 \mathrm{M}$ sodium hydroxide solution. The dye solutions $(10 \mathrm{~mL})$ with different $\mathrm{pH}$ values $(\mathrm{pH}$ solution $1.0,3.0,5.0$, and 7.0$)$ were added to the flasks containing $0.05 \mathrm{~g}$ of the biomass. They were kept at $100 \mathrm{rpm}$ for 180 minutes $\left(T=20^{\circ} \mathrm{C}\right)$. The $\mathrm{pH}$ of the samples was measured using a $\mathrm{pHmeter}$ (Gehaka PG200- São Paulo, SP, Brazil). The same test without the biosorbent was performed to discount process interference (control).

\section{Biosorption kinetics}

To determine the kinetic parameters, the biosorbent $(0.05 \mathrm{~g})$ was added to $10 \mathrm{~mL}$ of dye solution $\left(10\right.$ and $\left.50 \mathrm{mg} \mathrm{L}^{-1}\right)$. The flasks were kept in an incubator shaker at $100 \mathrm{rpm}$ at $20{ }^{\circ} \mathrm{C}$ for different times (from 1 to $180 \mathrm{~min}$ ). The samples were collected and centrifuged at $6000 \mathrm{rpm}$ for $10 \mathrm{~min}$, and the supernatant was used for the spectrophotometric quantification of the final concentration of dye in the solution. For each time, control samples were prepared (without biosorbent) and maintained under the same experimental conditions. 


\section{Biosorption isotherms}

Isotherms were studied at 20,30 , and $40{ }^{\circ} \mathrm{C}$ in 5 different concentrations ( 10 to $50 \mathrm{mg} \mathrm{L}^{-1}$ ) using the equilibrium time. The samples were centrifuged at $6000 \mathrm{rpm}$ for $10 \mathrm{~min}$, and the supernatant was used to quantify the concentration of dye in the final solution through the spectrophotometric method. The same test without biosorbent was performed (control).

\section{Statistical analysis and parameter estimation}

All the assays were carried out in triplicate. The results were expressed as mean \pm standard de- viation. The statistical analysis was performed using Origin software ${ }^{\mathrm{TM}}$ 8.5. Analysis of variance (ANOVA) and Tukey's test were used to identify significant differences between the means $(p \leq 0.05)$. Kinetic modeling was performed with the application of the non-linearized equations presented in Table1(a). The models depicted in Table 1(b) were used to analyze the isotherm biosorption mechanisms of the dyes in Açaí powder seeds. The experimental data included the nonlinear models using Origin software ${ }^{\mathrm{TM}} 8.5$ (nonlinear curve fit). The best fit was determined based on the correlation coefficient $\left(R^{2}\right)$.

Table 1 - Model and equation used to calculate the kinetic (a) and isothermal (b) parameters

\begin{tabular}{|c|c|c|}
\hline Model & & Equation \\
\hline \multicolumn{3}{|c|}{ Kinetic models (a) } \\
\hline Mass balance & $q_{t}=\frac{\left(\gamma_{0}-\gamma_{t}\right) V}{m}$ & 1 \\
\hline Selectivity coefficient & $\alpha_{\mathrm{AB}}=\frac{\mathrm{D}_{\mathrm{B}}}{L}$ & 2 \\
\hline Pseudo $1^{\circ}$ order & $q_{t}=q_{1} \cdot\left(1-\exp \left(-k_{1} \cdot t\right)\right)$ & 3 \\
\hline Pseudo $2^{\circ}$ order & $q_{t}=\frac{k_{2} \cdot q_{2}^{2} \cdot t}{1+k_{2} \cdot q_{2} \cdot t}$ & 4 \\
\hline Intraparticlediffusion & $q_{t}=\left(k_{\mathrm{d}} \cdot t^{0.5}\right)+C$ & 5 \\
\hline Blanchard & $q_{t}=\frac{\left(k_{4} \cdot q_{4} \cdot t\right)+\left(a_{4} \cdot q_{4}-1\right)}{k_{4} \cdot t+a_{4}}$ & 6 \\
\hline
\end{tabular}

Isotherms models (b)

\begin{tabular}{|c|c|c|}
\hline \multicolumn{3}{|c|}{ Isotherms models (b) } \\
\hline Langmuir & $q_{\mathrm{e}}=\frac{q_{\max } K_{\mathrm{L}} \gamma_{\mathrm{e}}}{1+K_{\mathrm{L}} \gamma_{\mathrm{e}}}, R_{\mathrm{L}}=\frac{1}{1+K_{\mathrm{L}} \gamma_{0}}$ & 7,8 \\
\hline Freundlich & $q_{\mathrm{e}}=K_{\mathrm{F}} \gamma_{e}^{1 / n}$ & 9 \\
\hline Temkin & $q_{\mathrm{e}}=B_{\mathrm{t}} \ln \left(A_{\mathrm{t}} \gamma_{\mathrm{e}}\right)$ & 10 \\
\hline DubininRadushkevich & $q_{\mathrm{e}}=q_{\max , \exp }\left(-k_{\mathrm{dr}} \varepsilon^{2}\right), \quad \varepsilon=R T\left(1+\frac{1}{\gamma_{\mathrm{e}}}\right), E=\frac{1}{\sqrt{2 k_{\mathrm{dr}}}}$ & $11,12,13$ \\
\hline Sips & $q_{e}=\frac{q_{\max } \cdot K_{\mathrm{s}} \cdot \gamma_{\mathrm{e}}^{\mathrm{s}}}{1+K_{\mathrm{s}} \cdot \gamma_{\mathrm{e}}^{\mathrm{s}}}$ & 14 \\
\hline
\end{tabular}

where: $q_{t}$ : is the adsorption capacity $\left(\mathrm{mg} \mathrm{g}^{-1}\right)$ at time $t(\mathrm{~min}) ; \gamma_{0}$ : initial solution concentration $\left(\mathrm{mg} \mathrm{L}^{-1}\right) ; \gamma_{t}$ : concentration of the solution at time $t\left(\mathrm{mg} \mathrm{L}^{-1}\right) ; V$ : solution volume (L); $m$ : mass of biosorbent $(\mathrm{g}) ; q_{1}$ and $q_{2}$ : theoretical maximum adsorption capacity $\left(\mathrm{mg} \mathrm{g}^{-1}\right) ; k_{1}$ : kinetic constant $\left(\mathrm{min}^{-1}\right) ; k_{2}$ : kinetic constant $\left(\mathrm{g} \mathrm{mg}^{-1} \mathrm{~min}^{-1}\right) ; k_{\mathrm{d}}$ : intraparticle diffusion coefficient $\left(\mathrm{g} \mathrm{mg}^{-1} \mathrm{~min}^{-0.5}\right)$; $C$ : diffusion constant in the boundary layer $\left(\mathrm{mg} \mathrm{g}^{-1}\right) ; q_{4}$ : theoretical maximum adsorption capacity $\left(\mathrm{mg} \mathrm{g}^{-1}\right) ; a_{4}$ and $k_{4}$ : Blanchard parameters; $q_{\mathrm{e}}$ : equilibrium sorption capacity $\left(\mathrm{mg} \mathrm{g}^{-1}\right), q_{\mathrm{max}}$ : maximum adsorption capacity $\left(\mathrm{mg} \mathrm{g}^{-1}\right) ; \gamma_{\mathrm{e}}$ : concentration of the solution in equilibrium (mg $\left.\mathrm{L}^{-1}\right)$, $K_{\mathrm{L}}$ : Langmuir constant $\left(\mathrm{L} \mathrm{mg}^{-1}\right), R_{\mathrm{L}}$ : separation factor, $n$ : constant related to the heterogeneity of the surface, $K_{\mathrm{F}}$ : Freundlich constant $\left(\mathrm{L} \mathrm{mg}^{-1}\right), B_{\mathrm{t}}$ : constant related to the adsorption heat; $A_{\mathrm{t}}$ : Temkin isothermal constant; $\varepsilon$ : Polanyi potential; $k_{\mathrm{dr}}$ : adsorption constant; $E$ : free energy of adsorption $\left(\mathrm{kJ} \mathrm{mol}^{-1}\right) ; K_{\mathrm{s}}$ : adsorption constant and Sips parameter; $R$ : universal gas constant $\left(\mathrm{J} \mathrm{K}^{-1} \mathrm{~mol}^{-1}\right) ; T$ : temperature $(\mathrm{K})$. 


\section{Results and discussion}

\section{Seeds morphology and composition}

The scanning electron microscopy (SEM) analysis (Fig. 3) revealed that the Açaí seed powder was composed of three different structures, defined as S1, S2, and S3. The Energy Dispersive X-ray detector (EDS) (Table 2), before and after the acid treatment and after biosorption of the dyes, indicated that more than $95 \%$ of the composition for all samples was represented by carbon and oxygen. These results are related to the organic structure of the seeds, which is rich in lignin and cellulose ${ }^{18}$ and due to the chemical composition of the dyes.

The presence of lignin and cellulose is a positive factor in biosorption due to the presence of functional groups of hydroxyl, carboxyl, amine, and carbonyl that can act as adsorptive sites. They promote the adsorption of the compounds of interest through the processes of complexation or ion ex- change. ${ }^{19}$ These groups have already been observed in the Açaí seeds structure, and they are associated with the large amount of cellulose in its composition. ${ }^{20}$ Junior et al..$^{18}$ investigated the ability of Açaí seeds to remove $\mathrm{Cu}^{2+}$ and $\mathrm{Zn}^{2+}$ from an aqueous solution.

S1 showed potassium in its composition before chemical modification, but it was not identified in the other parts of the seeds. Castro et al..$^{21}$ also identified the presence of potassium (K) and sulfur (S) in Açaí seeds. S3 presented silicium, while the internal structures of the seeds ( 1 and 2 ) did not present this element. Costa and Lima $^{20}$ analyzed the functional groups in the Açaí seeds, and they also identified silicium, sulfur, potassium, and calcium. The elements identified in the Açaí seeds are found in most of the seeds of different plants and fruit. They are essential for the initial growth, productivity, and protection of the internal or external integrity of the plants and fruits. ${ }^{22}$
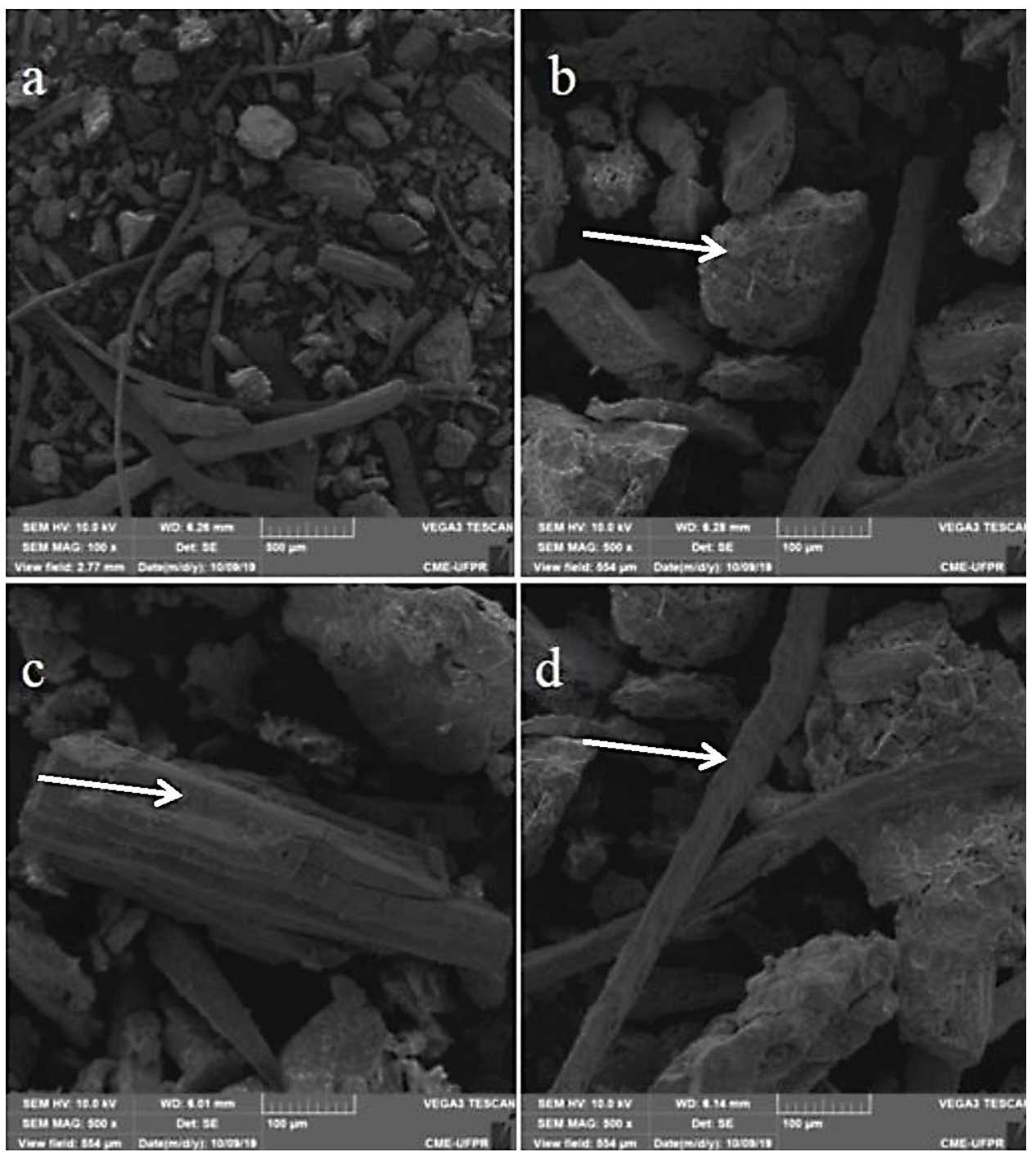

Fig. 3 - Scanning Electron Microscopy images of Açai seeds powder samples (MESH <80) with acid treatment at 100x magnification (a), S1 at 500x magnification (b), S2 at 500x magnification (c), and S3 at 500x magnification (d) 
Table 2 -Energy dispersive X-ray (EDS) performed on the different structures of the Açai seeds powder

\begin{tabular}{|c|c|c|c|c|c|c|c|c|c|c|c|c|c|c|c|}
\hline & \multicolumn{5}{|c|}{$\% \mathrm{~S} 1$} & \multicolumn{5}{|c|}{$\% \mathrm{~S} 2$} & \multicolumn{5}{|c|}{$\% \mathrm{~S} 3$} \\
\hline & WT & AT & $\mathrm{AY}$ & AR & MIX & WT & AT & AY & AR & MIX & WT & AT & AY & AR & MIX \\
\hline $\mathrm{C}$ & 62.92 & 60.94 & 57.95 & 62.71 & 63.88 & 60.12 & 58.88 & 53.94 & 58.41 & 55.87 & 62.97 & 61.13 & 62.66 & 65.66 & 60.09 \\
\hline $\mathrm{O}$ & 33.57 & 35.73 & 37.47 & 33.65 & 34.66 & 36.17 & 38.06 & 43.97 & 35.35 & 37.04 & 33.29 & 34.65 & 33.80 & 29.96 & 34.77 \\
\hline $\mathrm{N}$ & 2.50 & 2.89 & 3.91 & 3.29 & 1.46 & 3.41 & 2.22 & 2.08 & 6.02 & 6.86 & 2.89 & 2.85 & 3.11 & 2.74 & 4.16 \\
\hline $\mathrm{Si}$ & - & - & - & - & - & - & - & - & - & - & 0.85 & 1.19 & 0.43 & 1.16 & 0.86 \\
\hline S & 0.27 & 0.10 & 0.27 & 0.35 & - & - & - & - & 0.15 & - & - & - & - & 0.34 & 0.12 \\
\hline $\mathrm{Cl}$ & - & 0.20 & 0.21 & - & - & - & 0.84 & - & - & - & - & 0.18 & - & - & - \\
\hline $\mathrm{P}$ & - & 0.15 & 0.20 & - & - & - & - & - & - & - & - & - & - & 0.15 & - \\
\hline $\mathrm{K}$ & 0.74 & - & - & - & - & - & - & - & - & - & - & - & - & - & - \\
\hline $\mathrm{CO}$ & 96.49 & 96.67 & 95.42 & 96.36 & 98.54 & 96.29 & 96.94 & 97.92 & 93.76 & 92.91 & 96.26 & 95.78 & 96.46 & 95.62 & 94.86 \\
\hline $\mathrm{CO}_{\mathrm{M}}$ & 96.70 & & & & & 95.56 & & & & & 95.80 & & & & \\
\hline
\end{tabular}

Note: S1, S2, and S3: the three different structures found on the Açaí seeds powder samples; WT: Açaí seeds powder without treatment; AT: Açaí seeds powder with acid treatment before biosorption; AY Açaí seeds powder with acid treatment after biosorption with the AY dye; AR: Açaí seeds powder with acid treatment after biosorption with AR dye and MIX: Açaí seeds powder with acid treatment after biosorption with binary solution $(\mathrm{AY}+\mathrm{AR})$.

A small amount of chlorine was observed in the acid treated seeds before biosorption, possibly resulting from the chemical treatment carried out on the biosorbent. Despite this, $\mathrm{Cl}$ was not identified in the samples after the adsorption process (except for S1 after biosorption with AY), indicating that this element was either desorbed or it reacted with another component of the solution.

There was an increase in the amount of sulfur observed in $\mathrm{S} 1$ and in the appearance of this compound in S2 and S3 after adsorption. In addition, an increase in the concentration of nitrogen was also observed, especially in S2 after biosorption using AR dye in the binary solution. The presence of these compounds in the dye molecule justifies the increase caused by the dye biosorption. The results demonstrated that the use of the Açaí seed as a biosorbent is an alternative in the treatment of colored water.

\section{Point of zero charge (PZC), effect of solution $\mathrm{pH}_{\text {, }}$ and chemical modification of biosorbent}

The $\mathrm{pH}$ of the solution is an important parameter and can directly influence the interaction of the functional groups in the biosorbent as well as the solubility of the adsorbate. $\mathrm{PH}_{\mathrm{PZC}}$ aims to demonstrate the $\mathrm{pH}$ at which the surface of the biosorbent has a neutral charge. The plot of $\mathrm{pH}$ versus $\mathrm{pH}_{\mathrm{f}}$ indicates that the $\mathrm{pH}_{\mathrm{PZC}}$ of the biosorbent without treatment was 5.94, and that after acid treatment the value was 3.62. In aqueous solutions with a $\mathrm{pH}$ below $\mathrm{pH}_{\mathrm{PZC}}$ anion adsorption is favored due to the positive charge on the biosorbent surface at this $\mathrm{pH}$ value. In solutions with a higher $\mathrm{pH}$ than $\mathrm{pH}_{\mathrm{pZC}}$ the surface of the biosorbent will be negatively charged and therefore, attract cationic substances. ${ }^{17}$ Junior et al..$^{18}$ evaluated the $\mathrm{pH}_{\mathrm{PZC}}$ of the Açaí epicarp and obtained similar values.

The variation in the solution $\mathrm{pH}$ (from 1 to 7 ) was evaluated to determine the $\mathrm{pH}$ condition that most favors biosorption for the seeds with and without acid treatment. The increase in $\mathrm{pH}$ resulted in a decrease in biosorption capacity $\left(q_{\mathrm{e}}\right)$ for the two dyes studied, mainly for the biosorbent without treatment (Fig. 4). The reduction in $\mathrm{pH}$ from 7 to 1 resulted in an increase of $97 \%$ in the biosorption capacity of the dyes AY and AR for the biosorbent without treatment.

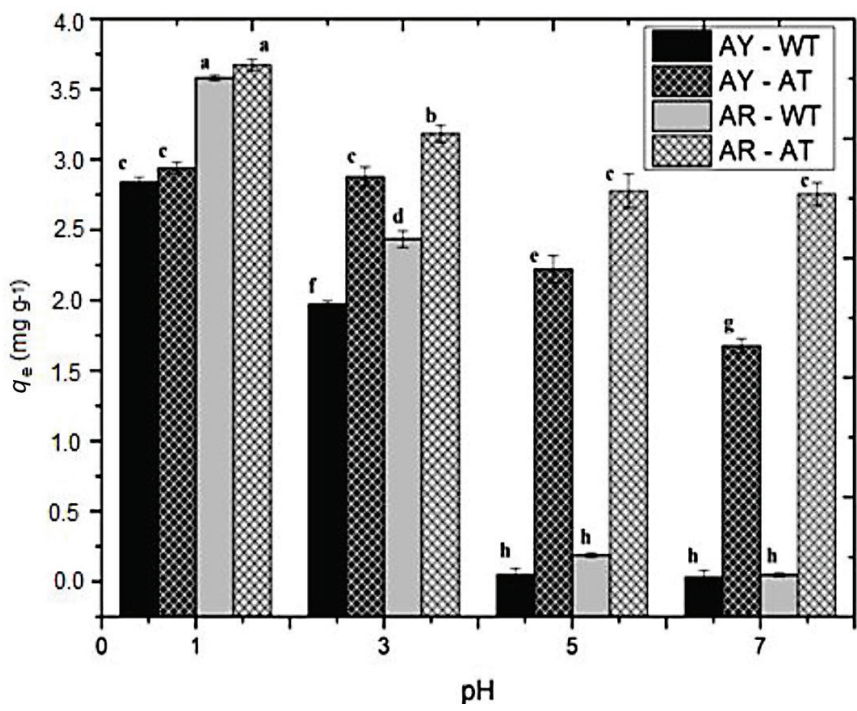

Fig. 4 -Biosorption capacity of textile dyes in Açai seeds powder (with and without acid treatment) for different $\mathrm{pH}$ solutions

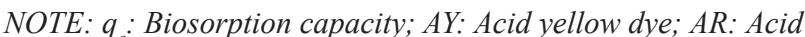
red dye; WT: Without treatment; AT: Acid treatment. Means with the same letter do not differ by Tukey test ( $p>0.05)$. 
The $\mathrm{pH}$ of the solution is thus directly related to the nature of the sorbate and the biosorbent. The biosorption of Cibaron Blue dye in bean peel was favored by decreasing the $\mathrm{pH}$ of the solution, ${ }^{7}$ where the results showed that the biosorbent charge is positive for $\mathrm{pH}<\mathrm{pH}_{\mathrm{pzc}}$. Errais et al. ${ }^{23}$ observed that $\mathrm{pH}$ 2.0 was the best condition for anionic dye biosorption in residual yeast. The same condition was found for the adsorption of acid dyes in acid-treated okara $^{24}$ and for the Phenol red and malachite green carbinol biosorption on barley seeds and biochar. ${ }^{6}$ However, the yield decreased with an increase in $\mathrm{pH}$. On the other hand, the adsorption of basic dyes in yeast showed a higher biosorption capacity in the $\mathrm{pH}$ range of $4-10 .^{25}$

Acid treatment resulted in a positive effect on the biosorption of the dyes AY and AR. A removal of $53 \%$ of the yellow dye occurred through biosorption using the untreated seeds (WT) within 180 minutes (100 rpm, $\mathrm{pH} \mathrm{3}$, and $\left.20^{\circ} \mathrm{C}\right)$. At the same operating conditions, there was a $77 \%$ removal in terms of adsorption than the biosorbent after acid treatment (AT). In terms of adsorption capacity $\left(q_{\mathrm{e}}\right)$, this represents a $46 \%$ higher biosorption after chemical modification. A similar result was found for the AR dye (180 minutes, $\mathrm{pH} 3,20^{\circ} \mathrm{C}$, and $\left.100 \mathrm{rpm}\right)$. The biosorbent without treatment reduced $46 \%$ of the dye contained in the solution. After chemical modification, more than $61 \%$ of the dye was removed, resulting in a $32 \%$ increase in the biosorption capacity. The reduction in $\mathrm{pH}$ from 3 to 1 showed no significant difference $(\mathrm{p}>0.05)$ for the yellow dye adsorption. However, an increase of $13 \%$ in the biosorption capacity was observed for the biosorbent after acid treatment with red dye.

Acid-treated biosorbent (AT) and the $\mathrm{pH}$ of the solution of 3 were used in the subsequent assays. This condition was chosen because it is below the $\mathrm{pH}_{\mathrm{PZC}}$ (favoring the adsorption of acid dyes) and less aggressive, considering that the main objective was to propose an alternative for the treatment of textile effluents.

\section{Biosorption kinetics}

The increase in dye concentration (10-50 $\left.\mathrm{mg} \mathrm{L}^{-1}\right)$ resulted in an increase in adsorption capacity $\left(q_{\mathrm{e}}\right)$ and more time was required to reach the equilibrium. The kinetic equilibrium time with the yellow dye (AY) was 30 minutes for the concentration of $10 \mathrm{mg} \mathrm{L}^{-1}\left(q_{\mathrm{e}}=1.40 \mathrm{mg} \mathrm{g}^{-1}\right)$, and 120 minutes for $50 \mathrm{mg} \mathrm{L}^{-1}\left(q_{\mathrm{e}}=7.54 \mathrm{mg} \mathrm{g}^{-1}\right)$ (Fig. 5a). About 50-60\% of the AY dye was removed in the first 15 minutes, and a $55-75 \%$ removal was observed at the equilibrium time. This result can be compared to the biosorption of Phenol red and malachite green carbinol $\left(X_{\mathrm{i}}=50 \mathrm{mg} \mathrm{L}^{-1}\right)$ using seeds and biochar of Barley, where the adsorption was more effective in the first 60 minutes and the biosorption equilibrium was reached in 90 minutes. $^{6}$

The removal of the acid red dye $\left(10 \mathrm{mg} \mathrm{L}^{-1}\right)$ in the first 15 minutes was $75 \%$ and the equilibrium time (30 minutes) removed about $88 \%\left(q_{\mathrm{e}}=1.76 \mathrm{mg} \mathrm{g}^{-1}\right)$ of the dye (Fig. 5b). For the solution with higher concentration $\left(50 \mathrm{mg} \mathrm{L}^{-1}\right), 48 \%$ of the dye was removed in the first 15 minutes of adsorption, and the kinetic equilibrium time was reached at 45 minutes with $64 \%$ of the dye removed $\left(q_{\mathrm{e}}=6.33 \mathrm{mg} \mathrm{g}^{-1}\right)$. In addition, the adsorption capacity of the AY was lower when compared to the AR for the $10 \mathrm{mg} \mathrm{L}^{-1}$ solution. However, in higher concentration, the AY adsorption capacity was higher than that of the AR dye.
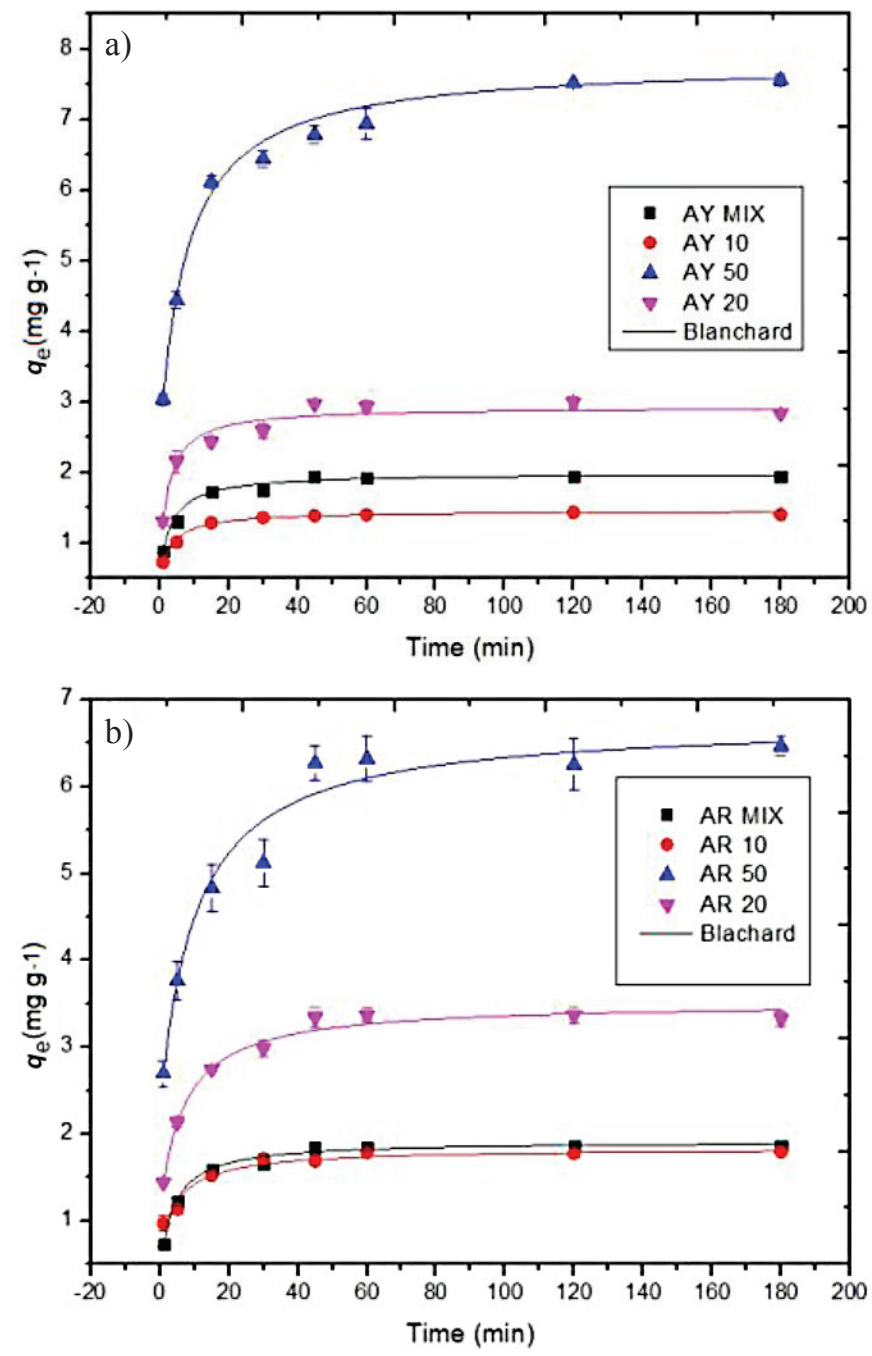

Fig. 5 - Biosorption kinetics of acid yellow and acid red dye using Açai seeds powder with acid treatment performed at 20 ${ }^{\circ} \mathrm{C}$ and $100 \mathrm{rpm}$

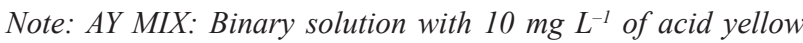
dye; AY 10: Single solution with $10 \mathrm{mg} \mathrm{L}^{-1}$ of acid yellow dye; AY 20: Single solution with $20 \mathrm{mg} \mathrm{L^{-1 }}$ of acid yellow dye; $A Y$ 50: Single solution with $50 \mathrm{mg} \mathrm{L^{-1 }}$ of acid yellow dye; $A R M I X$ : Binary solution with $10 \mathrm{mg} \mathrm{L^{-1 }}$ of acid red dye; AR 10: Single solution with $10 \mathrm{mg} \mathrm{L}^{-1}$ of acid red dye; AR 20: Single solution with $20 \mathrm{mg} \mathrm{L}^{-1}$ of acid red dye; AR 50: Single solution with 50 $m g L^{-1}$ of acid red dye. 
Wu et al. ${ }^{25}$ when studying the removal of Basic Violet 5BN and Basic Green dyes in residual yeast, also verified a decrease in the adsorption rate and an increase in the time necessary to reach equilibrium, when there was an increase in the initial concentration of the two studied dyes. A similar result was found by Castro et al. ${ }^{26}$ where the anionic dyes showed a higher biosorption capacity in residual yeasts at lower initial concentrations of the solution. The authors related the fact to the possible saturation of the active sites of the biosorbent in more concentrated solutions. On the other hand, Errais et al., ${ }^{23}$ when evaluating the adsorption of anionic dyes in clay, observed an increase in the capacity and adsorption speed when there was an increase in the initial concentration of the dye. This result can be related to the difference in the nature and surface of the biosorbent, which can provide completely different adsorption mechanisms.

The resulting interaction of the binary solution $(\mathrm{AY}+\mathrm{AR})$ demonstrated a beneficial effect, increasing the adsorption capacity of the two dyes. However, a longer time was required to reach kinetic equilibrium (45 minutes). Atun et al. ${ }^{27}$ studied the biosorption of a binary solution (Acid Blue 127 and Acid Yellow 17) using fly ash as an adsorbent. They found higher removal of dyes in the binary than in single solutions. The authors suggested that the dyes did not compete and that they were adsorbed at different binding sites resulting in an increase in adsorption capacity when using the same initial concentration. ${ }^{27}$

Table 3 -Kinetic parameters for the biosorption of acid yellow and acid red dyes in Açai seeds powder acid treated

\begin{tabular}{|c|c|c|c|c|c|c|}
\hline Blanchard & $k_{4}$ & $q_{4}$ & $a_{4}$ & & $R^{2}$ & \\
\hline AR 50 & $0.02 \pm 0.01$ & $6.75 \pm 0.17$ & $0.22 \pm 0.01$ & & 0.98 & \\
\hline AR 10 & $0.15 \pm 0.02$ & $1.84 \pm 0.03$ & $0.91 \pm 0.13$ & & 0.97 & \\
\hline AR MIX 10 & $0.16 \pm 0.03$ & $1.92 \pm 0.02$ & $0.67 \pm 0.03$ & & 0.99 & \\
\hline AY 50 & $0.02 \pm 3 \cdot 10^{-3}$ & $7.82 \pm 0.08$ & $0.19 \pm 0.01$ & & 0.99 & \\
\hline AY 10 & $0.24 \pm 0.05$ & $1.45 \pm 0.01$ & $1.07 \pm 0.06$ & & 0.99 & \\
\hline AY MIX 10 & $0.20 \pm-0.04$ & $1.99 \pm 0.03$ & $0.70 \pm 0.11$ & & 0.97 & \\
\hline Pseudo $2^{\circ}$ order & $k_{2}$ & $q_{\mathrm{e}}$ & & & $R^{2}$ & \\
\hline AR 50 & $0.09 \pm 0.02$ & $6.32 \pm 0.24$ & - & & 0.89 & \\
\hline AR 10 & $0.21 \pm 0.04$ & $1.80 \pm 0.04$ & - & & 0.89 & \\
\hline AR MIX 10 & $0.31 \pm 0.03$ & $1.88 \pm 0.02$ & - & & 0.99 & \\
\hline AY 50 & $0.06 \pm 0.02$ & $7.48 \pm 0.20$ & - & & 0.93 & \\
\hline AY 10 & $0.63 \pm 0.10$ & $1.42 \pm 0.02$ & - & & 0.96 & \\
\hline AY MIX 10 & $0.36 \pm 0.07$ & $1.92 \pm 0.03$ & - & & 0.94 & \\
\hline Pseudo $1^{\circ}$ order & $k_{1}$ & $q_{\mathrm{e}}$ & & & $R^{2}$ & \\
\hline AR 50 & $0.39 \pm 0.14$ & $6.07 \pm 0.34$ & - & & 0.74 & \\
\hline AR 10 & $0.15 \pm 0.02$ & $1.72 \pm 0.05$ & - & & 0.65 & \\
\hline AR MIX 10 & $0.44 \pm 0.08$ & $1.83 \pm 0.04$ & - & & 0.94 & \\
\hline AY 50 & $0.34 \pm 0.12$ & $7.19 \pm 0.30$ & - & & 0.77 & \\
\hline AY 10 & $0.66 \pm 0.16$ & $1.38 \pm 0.03$ & - & & 0.82 & \\
\hline AY MIX 10 & $0.64 \pm 0.20$ & $1.80 \pm 0.05$ & - & & 0.75 & \\
\hline Intraparticle diffusion & $k_{\mathrm{d} 1}$ & $C_{1}$ & $k_{\mathrm{d} 2}$ & $\mathrm{C}_{2}$ & $R_{1}^{2}$ & $R_{2}^{2}$ \\
\hline AR 50 & $2.22 \pm 0.27$ & $0.59 \pm 0.10$ & $6.07 \pm 0.12$ & $0.02 \pm 5 \cdot 10^{-3}$ & 0.92 & 0.71 \\
\hline AR 10 & $0.79 \pm 0.13$ & $0.19 \pm 0.03$ & $1.59 \pm 0.05$ & $0.02 \pm 5 \cdot 10^{-3}$ & 0.92 & 0.64 \\
\hline AR MIX 10 & $0.43 \pm 0.07$ & $0.31 \pm 0.04$ & $1.82 \pm 0.01$ & $0.03 \pm 9 \cdot 10^{-4}$ & 0.97 & 0.80 \\
\hline AY 50 & $1.98 \pm 0.06$ & $1.07 \pm 0.02$ & $5.45 \pm 0.09$ & $0.19 \pm 0.01$ & 0.99 & 0.99 \\
\hline AY 10 & $1.15 \pm 0.02$ & $0.03 \pm 3 \cdot 10^{-3}$ & $1.31 \pm 0.01$ & $0.01 \pm 2 \cdot 10^{-3}$ & 0.98 & 0.94 \\
\hline AY MIX 10 & $0.61 \pm 0.04$ & $0.29 \pm 0.01$ & $1.44 \pm 0.11$ & $0.07 \pm 0.02$ & 0.99 & 0.80 \\
\hline
\end{tabular}

NOTE: AR 50: Acid Red $50 \mathrm{mg} \mathrm{L}{ }^{-1}$; AR 10: Acid Red $10 \mathrm{mg} \mathrm{L}^{-1}$; AR MIX 10: Binary solution with $10 \mathrm{mg} \mathrm{L}^{-1}$ of acid red dye; AY 50: Acid Yellow $50 \mathrm{mg} \mathrm{L}^{-1}$; AY 10: Acid Yellow $10 \mathrm{mg} \mathrm{L}^{-1}$; AY MIX 10: Binary solution with $10 \mathrm{mg} \mathrm{L}^{-1}$ of acid yellow dye; $a_{4}$ and $k_{4}$ : Blanchard parameters; $q_{4}$ : theoretical maximum adsorption capacity $\left(\mathrm{mg} \mathrm{g}^{-1}\right) ; R^{2}$ : correlation coefficient; $k_{2}$ : kinetic constant $\left(\mathrm{g} \mathrm{mg}^{-1} \min ^{-1}\right) ; k_{1}$ : kinetic constant $\left(\min ^{-1}\right) ; q_{\mathrm{e}}$ : adsorption capacity at equilibrium time $\left(\mathrm{mg} \mathrm{g}^{-1}\right) ; k_{\mathrm{d} 1}$ and $k_{\mathrm{d} 2}$ : intraparticle diffusion coefficient $\left(\mathrm{g} \mathrm{mg}^{-1} \mathrm{~min}^{-0.5}\right) ; C_{1}$ and $C_{2}$ : diffusion constant in the boundary layer $\left(\mathrm{mg} \mathrm{g}^{-1}\right)$. 

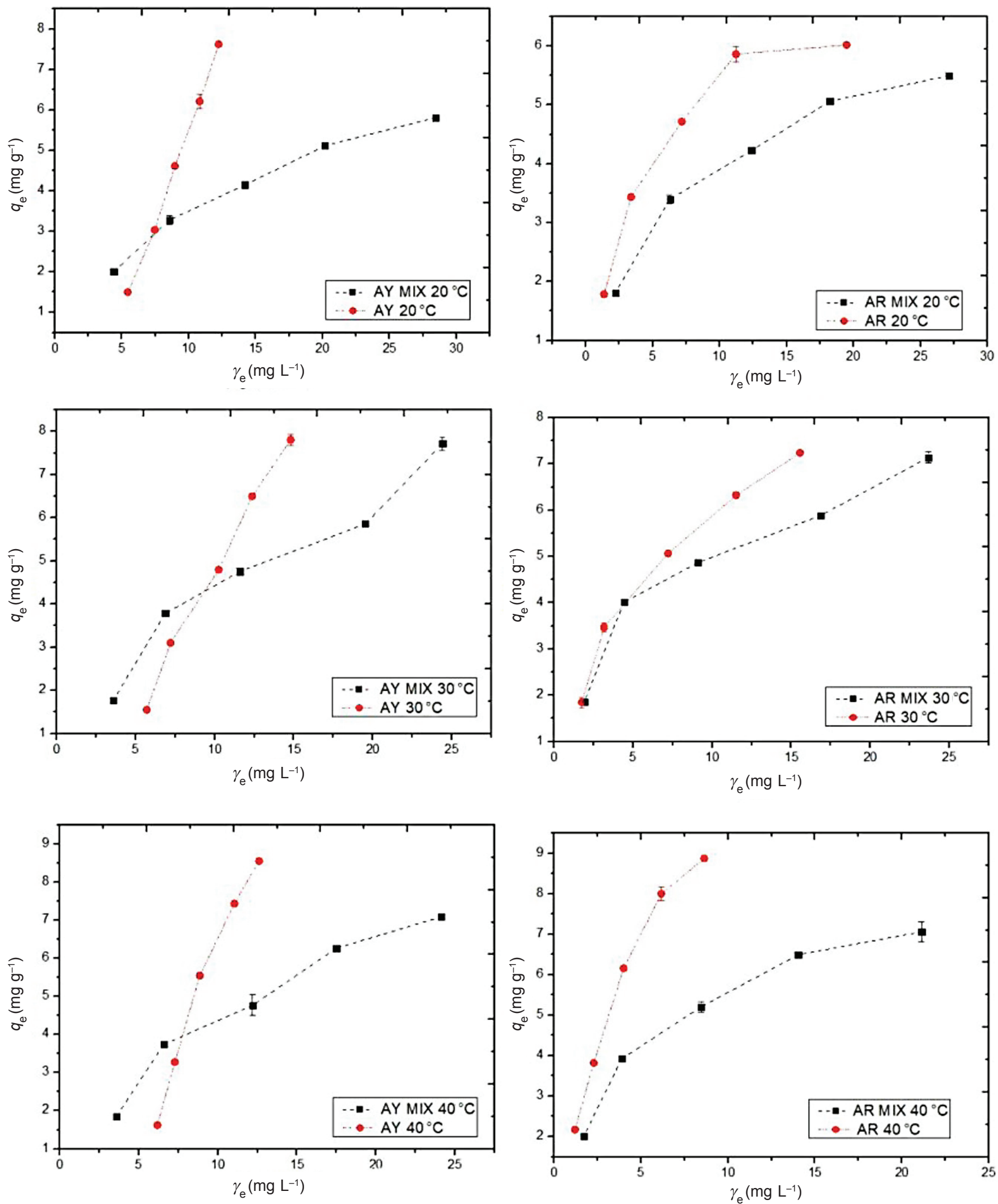

Fig. 6 - Effect of temperature (20,30, and $40^{\circ} \mathrm{C}$ ) and dye concentration of Açai seeds powder biosorption capacity NOTE: $q_{e}$ : equilibrium biosorption capacity; $\gamma_{e}$ : Equilibrium concentration of the solution; AY: Acid yellow dye single solution; AR: Acid red dye single solution; AY MIX: Acid yellow dye binary solution; AR MIX: Acid red dye binary solution. 
The three-parameter Blanchard (BTP) model best fitted the kinetic data with an $R^{2}$ between 0.966 (AR $10 \mathrm{mg} \mathrm{L}^{-1}$ ) and 0.996 (AR MIX $10 \mathrm{mg} \mathrm{L}^{-1}$ ) (Table 3). By evaluating the parameters of BTP model, an increase in the concentration of the dyes resulted in lower values of $k_{4}$, showing that, at higher concentrations, the mass transference resistance increased. This caused a reduction in the adsorption rate, resulting in a longer time to reach equilibrium. The pseudo-second order (PSO) model also properly fitted kinetic data.

The intraparticle diffusion model indicated that the diffusion step inside the particle did not limit the process. The plot $q_{\mathrm{e}}$ versus $t^{0.5}$ gave two linear regions and the first segment had the linear coefficient different from zero. The $k_{\mathrm{d}}$ value was the rate constant of the intraparticle diffusion model (Table 3 ); thus, the higher the value of this coefficient, the lower the mass resistance and the faster the adsorption occurs. The $C$ value is a constant associated with the boundary layer. Therefore, the higher the value of $C$, the higher the boundary layer effect. The first step presented the rate adsorption constant lower than the second step $\left(k_{\mathrm{d} 1}<k_{\mathrm{d} 2}\right)$, and the constant $C$ had an opposite effect (the values were higher at the second step $\left.\left(C_{1}>C_{2}\right)\right)$. Besides that, the values of the two constants $\left(k_{\mathrm{d}}\right.$ and $\left.C\right)$ were higher when increasing the initial concentration. The results suggested that the increase in concentration promoted an increase in the adsorption rate, and consequently an increase in the thickness of the boundary layer.

\section{Biosorption isotherm}

The influence of temperature in the biosorption process was evaluated at different temperatures. An improvement in biosorption (Fig. 6) at the highest temperature $\left(40^{\circ} \mathrm{C}\right)$ was found. The biosorption capacity of the AY dye at the different concentrations ranged from 8 to $17 \%$, being higher for the temperature of $40{ }^{\circ} \mathrm{C}$ when compared at $20^{\circ} \mathrm{C}$. For the adsorption of the AR dye, this effect was even more pronounced, resulting in an increase of 18 to $33 \%$ in the biosorption capacity at $40{ }^{\circ} \mathrm{C}$ compared with the results at $20^{\circ} \mathrm{C}$.

The way that biosorption occurred was different for dyes AY and AR in single solutions. The AY biosorption increased linearly with the increase in the initial concentration (isotherm type $\mathrm{C}$ - multilayer), while the biosorption of the dye AR showed a behavior that was typical of isotherm type L (concave curve), which is monolayer adsorption. This can be verified by the isotherm models (Tables 4 and 5). The biosorption of the AY dye presented a good correlation coefficient for the Freundlich mod$\mathrm{el}$, while for the AR dye, the Langmuir isotherm presented a good correlation coefficient.
Tables 4 and 5 show the isotherm parameters for the dye biosorption of AY and AR (single and binary solutions). The experimental data for the two dyes showed a good fit to the Sips model. The Sips model was proposed based on the Langmuir and Freundlich models. When the exponential (S) is equal to 1 , the Sips equation is reduced to the Langmuir model. When the value of $K<<1$, the equation is reduced to the Freundlich model. Analyzing the values found for $K_{\mathrm{s}}(\mathrm{AY})$, the model fit corroborates with the good fit of the Freundlich model. However, this was not observed for the adsorption of the acid dye in binary solution (AY MIX), inferring that there was a difference in the biosorption mechanisms resulting from the interaction between the dyes. The adsorption in the binary solution (AR MIX) resulted in the alteration of the parameter values although the mechanisms were like the adsorption of the individual solution.

From the analysis of Freundlich parameter, $n$, the biosorption of the dyes (AY, AY MIX, AR, and AR MIX) was favorable because in all the studied conditions, the values found for this parameter were between 0 and 1 . In addition, the adsorption constants of the AY MIX, AR, and AR MIX dyes obtained by the Langmuir model were used to calculate the separation factor $R_{\mathrm{L}}$. It was found that the biosorption was favorable $\left(0<R_{\mathrm{L}}<1\right)$ in all temperature conditions.

The $B_{\mathrm{t}}$ constant of the Temkin model is a parameter related to the adsorption heat. The values determined for this constant were positive for the two dyes studied, suggesting that an exothermic process took place. The $B_{t}$ constant in the adsorption of the individual solution of the AY dye presented with higher values when compared to the biosorption in a binary solution of AY MIX.

The Dubinin-Radushkevich isothermal model was used to calculate the adsorption energy and to verify whether the process was predominantly chemical $\left(8<E<18 \mathrm{~kJ} \mathrm{~mol}^{-1}\right)$ or predominantly physical $\left(E<8 \mathrm{~kJ} \mathrm{~mol}^{-1}\right)$. The results indicated that the forces involved in the biosorption of the AY dye were predominantly of the physical type, presenting values of $E<8 \mathrm{~kJ} \mathrm{~mol}^{-1}\left(E_{20}{ }^{\circ} \mathrm{C}=5.83 \mathrm{~kJ} \mathrm{~mol}^{-1}, E_{30}{ }^{\circ} \mathrm{C}\right.$ $=6.08 \mathrm{~kJ} \mathrm{~mol}^{-1}$ and $\left.E_{40}{ }^{\circ} \mathrm{C}=5.31 \mathrm{~kJ} \mathrm{~mol}^{-1}\right)$. The biosorption for the AY MIX dye showed an increase in free energy $E\left(E_{20{ }^{\circ} \mathrm{C}}=10.55 \mathrm{~kJ} \mathrm{~mol}^{-1}, E_{30{ }^{\circ} \mathrm{C}}=9.43\right.$ $\mathrm{kJ} \mathrm{mol}^{-1}$ and $E_{40}{ }^{\circ} \mathrm{C}=10.13 \mathrm{~kJ} \mathrm{~mol}^{-1}$ ) demonstrating that in a binary solution the adsorption was predominantly chemical. For the AR dye, the adsorption could be considered predominantly chemical because it presented with values of $E_{20}{ }^{\circ} \mathrm{C}=14.09 \mathrm{~kJ} \mathrm{~mol}^{-1}$, $E_{30}{ }^{\circ} \mathrm{C}=12.13 \mathrm{~kJ} \mathrm{~mol}^{-1}$ and $E_{40}{ }^{\circ}{ }^{\circ} \mathrm{C}=10.90 \mathrm{~kJ} \mathrm{~mol}^{-1}$. For the adsorption in the binary solution (AR MIX), the values of free energy also demonstrated that the process occurred in a predominantly chemical way 
$\left(E_{20{ }^{\circ} \mathrm{C}}=11.93 \mathrm{~kJ} \mathrm{~mol}^{-1}, E_{30}{ }^{\circ} \mathrm{C}=11.43 \mathrm{~kJ} \mathrm{~mol}^{-1}\right.$ and $E_{40{ }^{\circ} \mathrm{C}}=11.38 \mathrm{~kJ} \mathrm{~mol}^{-1}$. The conditions of 20 and $30{ }^{\circ} \mathrm{C}$, the values found were lower in relation to the process performed with a single solution. The variation in free adsorption energy found by the Dubinin-Radushkevich model corroborates with the results obtained previously, showing that the mechanisms were modified by the interaction between the dyes.

\section{Selectivity factor}

The selectivity factor $\left(\alpha_{\mathrm{AB}}\right)$ indicates the affinity of a compound with the adsorbent in relation to the other compound to be adsorbed. The biosorption selectivity of the dye AR MIX(A) in relation to AY MIX(B) was calculated through Equation 2. At the beginning, there was a higher affinity of adsorption for the acid AY MIX $\left(\alpha_{\mathrm{A}}=0.88 ; t=1 \mathrm{~min}\right)$. How-

Table 4 -Acid yellow single and binary solutions biosorption isotherm parameters

\begin{tabular}{|c|c|c|c|c|c|c|c|c|c|}
\hline$T\left({ }^{\circ} \mathrm{C}\right)$ & \multicolumn{3}{|r|}{20} & \multicolumn{3}{|r|}{30} & \multicolumn{3}{|r|}{40} \\
\hline Model & $R^{2}$ & & & $R^{2}$ & & & $R^{2}$ & & \\
\hline \multicolumn{10}{|c|}{ AY } \\
\hline \multirow{3}{*}{ Sips } & 0.99 & $K_{\mathrm{s}}$ & $1 \cdot 10^{-3} \pm 1.80 \cdot 10^{-4}$ & 0.99 & $K_{\mathrm{s}}$ & $2 \cdot 10^{-3} \pm 4.46 \cdot 10^{-4}$ & 0.99 & $K_{\mathrm{s}}$ & $8.76 \cdot 10^{-6} \pm 4.06 \cdot 10^{-6}$ \\
\hline & & $S$ & $2.77 \pm 0.15$ & & $S$ & $2.46 \pm 0.45$ & & $S$ & $5.57 \pm 0.27$ \\
\hline & & $q_{\max }$ & $15.02 \pm 1.60$ & & $q_{\max }$ & $13.33 \pm 7.75$ & & $q_{\max }$ & $9.02 \pm 0.42$ \\
\hline \multirow{3}{*}{ Langmuir } & - & $K_{\mathrm{L}}$ & - & & $K_{\mathrm{L}}$ & - & & $K_{\mathrm{L}}$ & - \\
\hline & & $R_{\mathrm{L}}$ & - & & $R_{\mathrm{L}}$ & - & & $R_{\mathrm{L}}$ & - \\
\hline & & $q_{\max }$ & - & & $q_{\max }$ & - & & $q_{\max }$ & - \\
\hline \multirow{2}{*}{ Freundlich } & 0.99 & $K_{\mathrm{F}}$ & $0.07 \pm 0.02$ & 0.99 & $K_{\mathrm{F}}$ & $0.06 \pm 0.01$ & 0.854 & $K_{\mathrm{F}}$ & $0.01 \pm 0.01$ \\
\hline & & $n$ & $0.52 \pm 0.03$ & & $n$ & $0.53 \pm 0.02$ & & $n$ & $0.38 \pm 0.05$ \\
\hline \multirow{2}{*}{ Temkin } & 0.97 & $B_{\mathrm{t}}$ & $7.42 \pm 0.61$ & 0.99 & $B_{\mathrm{t}}$ & $5.54 \pm 0.11$ & 0.997 & $B_{\mathrm{t}}$ & $10.36 \pm 0.29$ \\
\hline & & $A_{\mathrm{t}}$ & $0.22 \pm 0.011$ & & $A_{\mathrm{t}}$ & $0.23 \pm 4 \cdot 10^{-3}$ & & $A_{\mathrm{t}}$ & $0.19 \pm 1 \cdot 10^{-3}$ \\
\hline \multirow{3}{*}{ Dubinin Radushkevich } & 0.99 & $K_{\mathrm{dr}}$ & $0.02 \pm 7.58 \cdot 10^{-4}$ & & $K_{\mathrm{dr}}$ & $0.01 \pm 6.42 \cdot 10^{-4}$ & & $K_{\mathrm{dr}}$ & $0.02 \pm 2 \cdot 10^{-3}$ \\
\hline & & $E$ & 5.83 & & $E$ & 6.08 & & $E$ & 5.31 \\
\hline & & $q_{\max }$ & $270.06 \pm 13.44$ & & $q_{\max }$ & $196.12 \pm 8.92$ & 0.864 & $q_{\max }$ & $132.02 \pm 24.32$ \\
\hline \multicolumn{10}{|c|}{ AY MIX } \\
\hline \multirow{4}{*}{ Sips } & 0.99 & $K_{\mathrm{s}}$ & $0.02 \pm 0.01$ & 0.98 & $K_{\mathrm{s}}$ & $0.04 \pm 0.02$ & 0.99 & $K_{\mathrm{s}}$ & $0.04 \pm 0.013$ \\
\hline & & $S$ & $1.37 \pm 0.34$ & & $S$ & $1.64 \pm 0.51$ & & $S$ & $1.68 \pm 0.27$ \\
\hline & & $q_{\max }$ & $8.31 \pm 1.63$ & & $q_{\max }$ & $7.12 \pm 1.43$ & & $q_{\max }$ & $7.60 \pm 0.59$ \\
\hline & 0.99 & $K_{\mathrm{L}}$ & $0.03 \pm 0.01$ & & $K_{\mathrm{L}}$ & $0.04 \pm 0.01$ & & $K_{\mathrm{L}}$ & $0.06 \pm 0.014$ \\
\hline \multirow[t]{2}{*}{ Langmuir } & & $R_{\mathrm{L}}$ & 0.74 & & $R_{\mathrm{L}}$ & 0.70 & & $R_{\mathrm{L}}$ & 0.61 \\
\hline & & $q_{\max }$ & $11.80 \pm 0.92$ & 0.97 & $q_{\max }$ & $13.30 \pm 2.23$ & 0.99 & $q_{\max }$ & $11.95 \pm 1.27$ \\
\hline \multirow{2}{*}{ Freundlich } & 0.98 & $K_{\mathrm{F}}$ & $0.75 \pm 0.10$ & 0.96 & $K_{\mathrm{F}}$ & $0.71 \pm 0.07$ & 0.97 & $K_{\mathrm{F}}$ & $1.06 \pm 0.22$ \\
\hline & & $n$ & $0.62 \pm 0.04$ & & $n$ & $0.73 \pm 0.05$ & & $n$ & $0.62 \pm 0.07$ \\
\hline \multirow{3}{*}{ Temkin } & 0.99 & $B_{\mathrm{t}}$ & $2.72 \pm 0.08$ & 0.99 & $B_{\mathrm{t}}$ & $2.53 \pm 0.14$ & 0.99 & $B_{\mathrm{t}}$ & $2.72 \pm 0.06$ \\
\hline & & $A_{\mathrm{t}}$ & $0.30 \pm 0.01$ & & $A_{\mathrm{t}}$ & $0.56 \pm 0.03$ & & $A_{\mathrm{t}}$ & $0.57 \pm 0.03$ \\
\hline & 0.99 & $K_{\mathrm{dr}}$ & $5 \cdot 10^{-3} \pm 3.17 \cdot 10^{-4}$ & & $K_{\mathrm{dr}}$ & $6 \cdot 10^{-3} \pm 3.64 \cdot 10^{-4}$ & & $K_{\mathrm{dr}}$ & $5 \cdot 10^{-3} \pm 5.36 \cdot 10^{-4}$ \\
\hline \multirow[t]{2}{*}{ Dubinin Radushkevich } & & $E$ & 10.55 & & $E$ & 9.43 & & E & 10.13 \\
\hline & & $q_{\max }$ & $0.16 \pm 0.03$ & 0.97 & $q_{\max }$ & $0.40 \pm 0.11$ & 0.99 & $q_{\max }$ & $0.27 \pm 0.09$ \\
\hline
\end{tabular}

NOTE: $K_{\mathrm{s}}$ : adsorption constant and Sips parameter: $S ; q_{\mathrm{max}}$ : maximum adsorption capacity $\left(\mathrm{mg} \mathrm{g}^{-1}\right) ; K_{\mathrm{L}}$ : Langmuir constant $\left(\mathrm{L} \mathrm{mg}^{-1}\right)$; $R_{\mathrm{L}}$ : separation factor; $K_{\mathrm{F}}$ : Freundlich constant $\left(\mathrm{L} \mathrm{mg}^{-1}\right) ; n$ : constant related to the heterogeneity of the surface; $B_{\mathrm{t}}$ : constant related to the adsorption heat; $A_{\mathrm{t}}$ : Temkin isothermal constant; $K_{\mathrm{d}}$ : adsorption constant; $E$ : free energy of adsorption $\left(\mathrm{kJ} \mathrm{mol}^{-1}\right)$. 
ever, after 5 minutes, the adsorption became more selective for the $\operatorname{AR~} \operatorname{MIX}\left(\alpha_{\mathrm{AB}}=1.168 ; t=5 \mathrm{~min}\right)$. The selectivity factor at equilibrium time (180 minutes) also indicated that the biosorbent was more selective for the AR MIX dye $\left(\alpha_{\mathrm{AB}}=1.82\right)$.

Selectivity was also analyzed according to the temperature variation. An increase in temperature was more favorable for the adsorption of the AR MIX dye (Table 6). However, the increase in the initial concentration of the binary solution also increased the affinity of the AY MIX dye with the biosorbent, thus reducing the coefficient of selectivity to a value close to 1 . The affinity of the biosorbent was the same for both dyes $\left(50 \mathrm{mg} \mathrm{L}^{-1}\right)$, indicating that there was no competition for the binding sites between the two dyes. This result was a positive factor, as the objective was to remove the two dyes from the solution.

Table 5 - Acid red single and binary solutions biosorption isotherm parameters

\begin{tabular}{|c|c|c|c|c|c|c|c|c|c|}
\hline$T\left({ }^{\circ} \mathrm{C}\right)$ & \multicolumn{3}{|c|}{20} & \multicolumn{3}{|r|}{30} & \multicolumn{3}{|c|}{40} \\
\hline Model & $R^{2}$ & & & $R^{2}$ & & & $R^{2}$ & & \\
\hline \multicolumn{10}{|c|}{ AR } \\
\hline \multirow[t]{3}{*}{ Sips } & 0.999 & $K_{\mathrm{s}}$ & $0.26 \pm 0.01$ & 0.99 & $K_{\mathrm{s}}$ & $0.11 \pm 0.02$ & 0.99 & $K_{\mathrm{s}}$ & $0.15 \pm 0.01$ \\
\hline & & $S$ & $1.11 \pm 0.06$ & & $S$ & $0.78 \pm 0.19$ & & $S$ & $1.23 \pm 0.14$ \\
\hline & & $q_{\max }$ & $6.88 \pm 0.13$ & & $q_{\max }$ & $15.27 \pm 5.63$ & & $q_{\max }$ & $13.15 \pm 1.85$ \\
\hline \multirow[t]{3}{*}{ Langmuir } & 0.999 & $K_{\mathrm{L}}$ & $0.27 \pm 0.01$ & & $K_{\mathrm{L}}$ & $0.11 \pm 1.72$ & & $K_{\mathrm{L}}$ & $0.12 \pm 0.02$ \\
\hline & & $R_{\mathrm{L}}$ & 0.27 & & $R_{\mathrm{L}}$ & 0.47 & & $R_{\mathrm{L}}$ & 0.45 \\
\hline & & $q_{\max }$ & $7.16 \pm 0.06$ & 0.99 & $q_{\max }$ & $11.44 \pm 0.25$ & 0.99 & $q_{\max }$ & $17.71 \pm 1.72$ \\
\hline \multirow[t]{2}{*}{ Freundlich } & 0.973 & $K_{\mathrm{F}}$ & $2.18 \pm 0.15$ & 0.99 & $K_{\mathrm{F}}$ & $1.99 \pm 0.09$ & 0.97 & $K_{\mathrm{F}}$ & $2.18 \pm 0.15$ \\
\hline & & $n$ & $0.67 \pm 0.05$ & & $n$ & $0.47 \pm 0.02$ & & $n$ & $0.67 \pm 0.05$ \\
\hline \multirow[t]{2}{*}{ Temkin } & 0.996 & $B_{\mathrm{t}}$ & $1.51 \pm 0.05$ & 0.99 & $B_{\mathrm{t}}$ & $2.73 \pm 0.11$ & 0.96 & $B_{\mathrm{t}}$ & $3.38 \pm 0.33$ \\
\hline & & $A_{\mathrm{t}}$ & $2.83 \pm 0.29$ & & $A_{\mathrm{t}}$ & $0.09 \pm 0.094$ & & $A_{\mathrm{t}}$ & $1.42 \pm 0.17$ \\
\hline \multirow[t]{3}{*}{ Dubinin Radushkevich } & 0.979 & $K_{\mathrm{dr}}$ & $2 \cdot 10^{-3} \pm 2.08 \cdot 10^{-4}$ & 0.99 & $K_{\mathrm{dr}}$ & $3 \cdot 10^{-3} \pm 9.84 \cdot 10^{-5}$ & & $K_{\mathrm{dr}}$ & $4 \cdot 10^{-3} \pm 2.95 \cdot 10^{-4}$ \\
\hline & & $E$ & 14.09 & & $E$ & 12.13 & & $E$ & 10.90 \\
\hline & & $q_{\max }$ & $0.05 \pm 0.01$ & & $q_{\max }$ & $0.14 \pm 0.01$ & 0.97 & $q_{\max }$ & $0.56 \pm 0.16$ \\
\hline \multicolumn{10}{|c|}{ AR MIX } \\
\hline \multirow[t]{3}{*}{ Sips } & 0.998 & $K_{\mathrm{s}}$ & $0.14 \pm 0.01$ & 0.99 & $K_{\mathrm{s}}$ & $0.14 \pm 0.01$ & 0.99 & $K_{\mathrm{s}}$ & $0.18 \pm 0.006$ \\
\hline & & $S$ & $0.90 \pm 0.14$ & & $S$ & $1.72 \pm 0.12$ & & $S$ & $1.29 \pm 0.08$ \\
\hline & & $q_{\max }$ & $8.74 \pm 1.32$ & & $q_{\max }$ & $6.22 \pm 0.19$ & & $q_{\max }$ & $7.67 \pm 0.28$ \\
\hline \multirow[t]{3}{*}{ Langmuir } & 0.999 & $K_{\mathrm{L}}$ & $0.14 \pm 0.008$ & & $K_{\mathrm{L}}$ & $0.16 \pm 0.03$ & & $K_{\mathrm{L}}$ & $0.17 \pm 0.01$ \\
\hline & & $R_{\mathrm{L}}$ & 0.42 & & $R_{\mathrm{L}}$ & 0.38 & & $R_{\mathrm{L}}$ & 0.37 \\
\hline & & $q_{\max }$ & $7.95 \pm 0.13$ & 0.96 & $q_{\max }$ & $8.28 \pm 0.92$ & 0.99 & $q_{\max }$ & $9.25 \pm 0.38$ \\
\hline \multirow[t]{2}{*}{ Freundlich } & 0.991 & $K_{\mathrm{F}}$ & $1.41 \pm 0.13$ & 0.90 & $K_{\mathrm{F}}$ & $1.42 \pm 0.20$ & 0.97 & $K_{\mathrm{F}}$ & $1.63 \pm 0.17$ \\
\hline & & $n$ & $0.47 \pm 0.03$ & & $n$ & $0.52 \pm 0.07$ & & $n$ & $0.53 \pm 0.05$ \\
\hline \multirow[t]{2}{*}{ Temkin } & 0.999 & $B_{\mathrm{t}}$ & $1.81 \pm 0.03$ & 0.97 & $B_{\mathrm{t}}$ & $1.94 \pm 0.16$ & 0.99 & $B_{\mathrm{t}}$ & $2.13 \pm 0.04$ \\
\hline & & $A_{\mathrm{t}}$ & $1.25 \pm 0.07$ & & $A_{\mathrm{t}}$ & $1.39 \pm 0.16$ & & $A_{\mathrm{t}}$ & $1.52 \pm 0.05$ \\
\hline \multirow[t]{3}{*}{ Dubinin Radushkevich } & 0.994 & $K_{\mathrm{dr}}$ & $3 \cdot 10^{-3} \pm 1.98 \cdot 10^{-4}$ & & $K_{\mathrm{dr}}$ & $4 \cdot 10^{-3} \pm 4.92 \cdot 10^{-4}$ & & $K_{\mathrm{dr}}$ & $4 \cdot 10^{-3} \pm 3.1 \cdot 10^{-4}$ \\
\hline & & $E$ & 11.93 & & E & 11.43 & & E & 11.38 \\
\hline & & $q_{\max }$ & $0.08 \pm 0.01$ & 0.92 & $q_{\max }$ & $0.13 \pm 0.05$ & 0.98 & $q_{\max }$ & $0.16 \pm 0.04$ \\
\hline
\end{tabular}

NOTE: $K_{\mathrm{s}}$ : adsorption constant and Sips parameter: $S ; q_{\mathrm{max}}:$ maximum adsorption capacity $\left(\mathrm{mg} \mathrm{g}^{-1}\right) ; K_{\mathrm{L}}$ : Langmuir constant (L mg $\left.{ }^{-1}\right)$; $R_{\mathrm{L}}$ : separation factor; $K_{\mathrm{F}}$ : Freundlich constant $\left(\mathrm{L} \mathrm{mg}^{-1}\right) ; n$ : constant related to the heterogeneity of the surface; $B_{\mathrm{t}}$ : constant related to the adsorption heat; $A_{\mathrm{t}}$ : Temkin isothermal constant; $K_{\mathrm{dr}}$ : adsorption constant; $E$ : free energy of adsorption $\left(\mathrm{kJ} \mathrm{mol}^{-1}\right)$. 
Table 6 -Selectivity factor for the biosorption of the binary solution in chemically modified Açai seeds powder at 20,30 , and $40^{\circ} \mathrm{C}$

\begin{tabular}{c|c|c|c}
\hline$\gamma_{\mathrm{i}}$ & $\alpha_{\mathrm{AB} 20{ }^{\circ} \mathrm{C}}$ & $\alpha_{\mathrm{AB} 30{ }^{\circ} \mathrm{C}}$ & $\alpha_{\mathrm{AB} 40{ }^{\circ} \mathrm{C}}$ \\
\hline 10 & $1.80 \pm 0.03$ & $1.97 \pm 0.01$ & $2.28 \pm 0.02$ \\
20 & $1.41 \pm 0.05$ & $1.65 \pm 0.04$ & $1.77 \pm 0.03$ \\
30 & $1.17 \pm 0.05$ & $1.30 \pm 0.06$ & $1.57 \pm 0.02$ \\
40 & $1.10 \pm 0.02$ & $1.16 \pm 0.03$ & $1.29 \pm 0.02$ \\
50 & $0.99 \pm 0.05$ & $0.95 \pm 0.14$ & $1.14 \pm 0.15$ \\
\hline
\end{tabular}

NOTE: $\gamma_{\mathrm{i}}$ : Initial solution concentration $\mathrm{mg} \mathrm{L}^{-1} ; \alpha_{\mathrm{AB}}$ : biosorption selectivity factor of the dye AR in relation to AY.

These results justify the results found in the isothermal assays. The tests carried out on the binary solution $(\mathrm{AY}+\mathrm{AR})$ showed that there was an interaction between the dyes which modified the biosorption mechanisms mainly for the conditions where the initial solution was more concentrated. A reduction occurred in the adsorption capacity of the AY dye when comparing the process performed in the binary solution to the single component solution. On the other hand, this result was not so pronounced for the AR MIX. The temperature of $40{ }^{\circ} \mathrm{C}$ showed an improvement in biosorption capacity when compared to the individual dye solution.

\section{Conclusions}

The biosorbent showed high potential for the removal of textile dyes through the biosorption process, especially after acid treatment. About $75 \%$ and $88 \%$ of the AY and AR dyes were removed at the equilibrium time, respectively. The variation in the $\mathrm{pH}$ indicated that the adsorption was favored in an acid $\mathrm{pH}$. No competition was observed between the dyes during binary adsorption. Açaí seeds, an Amazonian by-product that is generated in high quantities, showed to be an excellent biosorbent for simple and binary dyes solutions. Therefore, the results of this study indicate that this agro-industrial by-product can be used in wastewater pretreatment, especially in textile industry.

\section{ACKNOWLEDGEMENTS}

The authors would like to thank Universidade Federal do Paraná (UFPR) and Universidade Tecnológica Federal do Paraná (UTFPR) for providing the infrastructure. Additionally, we would like to thank Coordenação de Aperfeiçoamento de Pessoal de Nivel Superior (CAPES) (40001016019P6), Conselho Nacional de Desenvolvimento Científico e Tecnológico (CNPq) (Process304722/2019-7) for financial support. Finally, we would like to thank Centro de Microscopia Eletrônica (CME - UFPR).
The authors declare that they have no known competing financial interests or personal relationships that could have appeared to influence the work reported in this paper.

\section{References}

1. Guaratini, C. C. I., Zanoni, M. V. B., Corantes Têxteis: Revisão, Quim. Nova. 23 (2000) 71.

2. Zümriye Aksu, G. D., A comparative study on the biosorption characteristics of some yeasts for Remazol Blue reactive dye, Chemosphere 50 (2002) 1075.

3. Idan, I. J., Md. Jamil, S. N. A. B., Abdullah, L. C., Choong, T. $S$. Y., Removal of reactive anionic dyes from binary solutions by adsorption onto quaternized kenaf core fiber, Int. J. Chem. Eng. 2017 (2017).

doi: https://doi.org/10.1155/2017/9792657

4. El-Ahmady El-Naggar, N., Rabei, N. H., El-Malkey, S. E., Eco-friendly approach for biosorption of $\mathrm{Pb}^{2+}$ and carcinogenic Congo red dye from binary solution onto sustainable Ulva lactuca biomass, Sci. Rep. 10 (2020) 1. doi: https://doi.org/10.1038/s41598-020-73031-1

5. Bhattacharya, R., Chatterjee, R., Mandal, A. K. A., Mukhopadhyay, A., Basu, S., Giri, A. K., Chatterji, U., Bhattacharjee, $P$., Theaflavin-containing black tea extract: A potential DNA methyltransferase inhibitor in human colon cancer cells and ehrlich ascites carcinoma-induced solid tumors in mice, Nutr. Cancer. 0 (2020) 1. doi: https://doi.org/10.1080/01635581.2020.1828943

6. El Mansouri, F., El Farissi, H., Zerrouk, M. H., Cacciola, F., Bakkali, C., Brigui, J., Lovillo, M. P., Esteves da Silva, J. C. G., Dye removal from colored textile wastewater using seeds and biochar of barley (Hordeum vulgare 1.), Appl. Sci. 11 (2021) 5125 doi: https://doi.org/10.3390/app11115125

7. Grabi, H., Derridj, F., Lemlikchi, W., Guénin, E., Studies of the potential of a native natural biosorbent for the elimination of an anionic textile dye Cibacron Blue in aqueous solution, Sci. Rep. 11 (2021) 1. doi: https://doi.org/10.1038/s41598-021-88657-y

8. Kyzas, G., Fu, J., Matis, K., New biosorbent materials: Selectivity and bioengineering insights, Processes 2 (2014) 419. doi: https://doi.org/10.3390/pr2020419

9. Rufino, M. do S. M., Pérez-Jiménez, J., Arranz, S., Alves, R. E., de Brito, E. S., Oliveira, M. S. P., Saura-Calixto, F., Açaí (Euterpe oleraceae) "BRS Pará": A tropical fruit source of antioxidant dietary fiber and high antioxidant capacity oil, Food Res. Int. 44 (2011) 2100. doi: https://doi.org/10.1016/j.foodres.2010.09.011

10. Martins, M. A., Henrique, L., Mattoso, C., Dalton, J., Pessoa, C., Comportamento térmico e caracterização morfológica das fibras de mesocarpo e caroço do açaí (Euterpe oleracea Mart.) 1, Rev. Bras. Frutic. (2009) 1150.

11. Ribeiro, V. R., Fernandes, I. de A. A., Mari, I. P., Stafussa, A. P., Rossetto, R., Maciel, G. M., Haminiuk, C. W. I., Bringing together Saccharomyces cerevisiae and bioactive compounds from plants: A new function for a well-known biosorbent, J. Funct. Foods. 60 (2019) 103433. doi: https://doi.org/10.1016/j.jff.2019.103433

12. Fomina, M., Gadd, G. M., Biosorption: Current perspectives on concept, definition and application, Bioresour. Technol. (2013). doi: https://doi.org/10.1016/j.biortech.2013.12.102 
13. Park, D., Yun, Y., Park, J. M., The past, present, and future trends of biosorption, (2010) 86. doi: https://doi.org/10.1007/s12257-009-0199-4

14. Markandeya, S. P. S., Mohan, D., Toxicity of disperse dyes and its removal from wastewater using various adsorbents: A review, Res. J. Environ. Toxicol. 11 (2017) 72. doi: https://doi.org/10.3923/rjet.2017.72.89

15. Dotto, G. L., Lima, E. C., Pinto, L. A. A., Bioresource technology biosorption of food dyes onto Spirulina platensis nanoparticles: Equilibrium isotherm and thermodynamic analysis, Bioresour. Technol. 103 (2012) 123. doi: https://doi.org/10.1016/j.biortech.2011.10.038

16. Rubio, F. T. V., Maciel, G. M., da Silva, M. V., Corrêa, V. G., Peralta, R. M., Haminiuk, C. W. I., Enrichment of waste yeast with bioactive compounds from grape pomace as an innovative and emerging technology: Kinetics, isotherms and bioaccessibility, Innov. Food Sci. Emerg. Technol. 45 (2017) 18. doi: https://doi.org/10.1016/j.ifset.2017.09.004

17. Regalbuto, J. R., Robles, J. O., The engineering of Pt/carbon catalyst preparation, Univ. Illinois, Chicago (2004) 13

18. Gonçalves Junior, A. C., Coelho, G. F., Schwantes, D., Rech, A. L., Campagnolo, M. A., Miola, A. J., Biosorption of $\mathrm{Cu}(\mathrm{II})$ and $\mathrm{Zn}(\mathrm{II})$ with açaí endocarp Euterpe oleracea M. in contaminated aqueous solution, Acta Sci. Technol. 38 (2016) 361 .

doi: https://doi.org/10.4025/actascitechnol.v38i3.28294

19. Ngah, W. S. W., Hanafiah, M. A. K. M., Removal of heavy metal ions from wastewater by chemically modified plant wastes as adsorbents: A review, Bioresour. Technol. 99 (2008) 3935.

doi: https://doi.org/10.1016/j.biortech.2007.06.011

20. Costa, P. H., Lima, M., 11 - Micromorfologia e grupos funcionais do endo e mesocarpo do açaí, (2017) 1.

21. de Castro, D. A. R., da Silva Ribeiro, H. J., Ferreira, C. C., de Andrade Cordeiro, M., Guerreiro, L. H. H., Pereira, A. M., dos Santos, W. G., Santos, M. C., de Carvalho, F. B., Junior J. O. C. S., e Oliveira, R. L., Duvoisin, S., Borges, L. E. P., Machado, N. T., Fractional Distillation of Bio-Oil Produced by Pyrolysis of Açaí (Euterpe oleracea) Seeds, in: H.A.-H Ibrahim (Ed.), Fractionation, IntechOpen, London, 2019: pp. $61-80$. doi: https://doi.org/10.5772/intechopen.79546

22. Tripathi, D. K., Singh, V. P., Chauhan, D. K., Prasad, S. M., Dubey, $N$. K., Role of macronutrients in plant growth and acclimation: Recent advanves and future prospective, Improv. Crop. Era Clim. Chang. 2 (2014) 1. doi: https://doi.org/10.1007/978-1-4614-8824-8

23. Errais, E., Duplay, J., Darragi, F., M'Rabet, I., Aubert, A., Huber, F., Morvan, G., Efficient anionic dye adsorption on natural untreated clay: Kinetic study and thermodynamic parameters, Desalination 275 (2011) 74. doi: https://doi.org/10.1016/j.desal.2011.02.031

24. Gao, J., Wang, J., Yang, C., Wang, S., Peng, Y., Binary biosorption of Acid Red 14 and Reactive Red 15 onto acid treated okara: Simultaneous spectrophotometric determination of two dyes using partial least squares regression, Chem. Eng. J. 171 (2011) 967. doi: https://doi.org/10.1016/j.cej.2011.04.047

25. Wu, Y., Jiang, L., Wen, Y., Zhou, J., Biosorption of basic violet $5 \mathrm{BN}$ and basic green by waste brewery's yeast from single and multicomponent systems, Envrionment Sci. Pollut. Res. (2011) 510. doi: https://doi.org/10.1007/s11356-011-0577-2

26. Castro, K. C. De, Cossolin, A. S., Cristina, H., Biosorption of anionic textile dyes from aqueous solution by yeast slurry from brewery, 60 (2017) 1.

27. Atun, G., Ayar, N., Kurtoğlu, A. E., Ortaboy, S., A comparison of sorptive removal of anthraquinone and azo dyes using fly ash from single and binary solutions, J. Hazard. Mater. 371 (2019) 94. doi: https://doi.org/10.1016/j.jhazmat.2019.03.006 